\title{
IBA EFFICIENCY ON MINI-CUTTING ROOTING FROM TEAK (Tectona grandis Linn F.) CLONES ${ }^{1}$
}

\author{
Yorleny Badilla ${ }^{2 *}$, Aloisio Xavier ${ }^{3}$, Olman Murillo ${ }^{2}$ and Haroldo Nogueira de Paiva ${ }^{3}$
}

\begin{abstract}
${ }^{1}$ Received on 04.08.2014 accepted for publication on 23.03.2016.
${ }^{2}$ Instituto Tecnológico de Costa Rica, Escuela de Ingenería Forestal, Cartago - Costa Rica. E-mail: <yorlenybadilla@yahoo.es> and <olmuga@yahoo.es>.

${ }^{3}$ Universidade Federal de Viçosa, Centro de Ciências Agrárias, Departamento de Engenharia Florestal, Viçosa, MG - Brasil. E-mail: <xavier@ufv.br> and <hnpaiva@ufv.br>.

*Corresponding author.
\end{abstract}

\begin{abstract}
This study aimed to evaluate IBA efficiency in mini-cuttings rooting based on four Tectona grandis clones. Vegetative samples were collected in a hydroponic mini-clonal hedge in Verde Novo reforestation company at Colider, Mato Grosso. A factorial arrangement ( 4 x 6) was utilized, based on Carapá, Ipê, GU5 and TB7 clones vs six IBA dosages $\left(0,1000,2000,4000,8000\right.$ and $\left.16000 \mathrm{mg} \mathrm{L}^{-1}\right)$, in a randomized block design based on three repetitions and 16 mini-cuttings per experimental unit. Cutting evaluations were based on survival and rooting rates after greenhouse conditions, after shadow-house, and at sun exposure, besides, total height, collar diameter, aerial and root biomass were also analyzed. Results registered a $95,4 \%$ average survivance rate as well as a $91,8 \%$ rooting rate, considered as very high for this tree species. IBA dosages utilization did not produce a significative effect on rooting mini-cuttings from these investigated clones. However, there were different responses among clones, which suggests a genotypic effect.
\end{abstract}

Keywords: Vegetative propagation; Clonal forestry; Mini-cutting technique.

\section{EFICIÊNCIA DO AIB NO ENRAIZAMENTO DE MINIESTACAS DE CLONES DE TECA (Tectona grandis Linn F.)}

\begin{abstract}
RESUMO-Este estudo teve como objetivo avaliar a eficiência do ácido indol-butirico (AIB) no enraizamento de miniestacas de quatro clones de Tectona grandis. As miniestacas foram coletadas em minijardim clonal conduzido em sistema de hidroponia. Adotou-se arranjo fatorial (4 $x$ 6), considerando quatro clones (Carapá, Ipê, GU5 e TB7) e seis dosagens de AIB (0, 1000, 2000, 4000, 8000 e $16000 \mathrm{mg} \mathrm{L}^{-1}$ ), disposto no delineamento experimental de blocos ao acaso, em três repetições e parcelas compostas de 16 miniestacas. Foram realizadas avaliações de sobrevivência e de enraizamento na saída de casa de vegetação, de sobrevivência na saída da casa de sombra e a pleno sol foram avaliadas a altura, diâmetro de colo, biomassa da parte aérea e do sistema radicial. De acordo com os resultados encontrados, observou-se que as miniestacas dos clones avaliados apresentaram em média um percentual de sobrevivência de $95,4 \%$ e um indice de enraizamento de $91,8 \%$, considerados altos para a espécie. A utilização de doses de AIB não teve efeito significativo no enraizamento das miniestacas dos clones avaliados, contudo foi observada resposta diferenciada entre os quatro clones, o que sugere efeito genotípico.
\end{abstract}

Palavras-chave: Propagação vegetativa; Silvicultura clonal; Miniestaquia. 


\section{INTRODUCTION}

Teak (Tectona grandis Linn f.), which belongs to the Lamiaceae family, is from India, Thailand, Laos, Burma, Cambodia, Vietnam and Java (LAMPRECHT, 1990), and it is nowadays one of the most valued tree species in the forest market in countries from the different continents. The main features of the teak wood are concerning durability, stability, pre-treatment facility, natural resistance to fungi, insects, pests, drill bugs, attack, allied to drawing and color considered important qualitative aspects in the timber market this species (GOH; GALIANA, 2000).

According to Oliveira (2003), the commercial forestation with this species has been made in high scale for more than one hundred years, especially in Asia. However, most of teak traditional plantations in the world are made with seedlings obtained in front of sexed propagation (via seminiferous). Recently, programs of genetic improvement have concentrated in the development of trees clones of superior genotype (KAOSA-ARD, 1998; MURILLO; BADILLA, 2004a); and, at the same time, some work aiming to evaluate the capacity of this species regarding vegetative propagation by cuttings, by grafting and by micropropagation has already been tested (MASCARENHAS; MARALIDHARAM, 1993; MONTEUUIS et al., 1995; MONTEUUIS et al., 1998; GATTI, 2002; MURILLO; BADILLA, 2004b; HUSEN, 2011).

The mass vegetative propagation of the forest species has improved with the rooting cuttings increase, which was got, especially, with the development of micro-cuttings and mini-cuttings techniques that enabled considerable due gains, mainly, in the rooting index increase and time reduction for seedling formation (XAVIER; WENDLING, 1998; WENDLING, 1999; WENDLING et al., 2000). The mini-cutting used is justified when there is availability of highly productive genotype, seed shortage or difficulty in the propagation via seminal (XAVIER et al., 2003).d

The formation of adventitious roots is the first and most important cutting step, bearing in mind that, most of losses occur due to low root quality (DE KLERK et al., 1999), which may be consequence of the genotype, age and nutrition of the plant that provides propagating material, environmental conditions, hormonal balance, cuttings collect seasons (HARTMANN et al., 2011), besides crop treatments, such as irrigations and diseases control. In part, these obstacles can be solved by using phytoregulators, especially those of the auxin group, that beside stimulating cutting rooting, the increasing percentage of root formation, enhance the number and root formed quality, improve the rooting uniformity and reduce the cuttings permanence in case of rooting. (ONO; RODRIGUES, 1996; ZUFFELLATO-RIBAS; RODRIGUES, 2001).

Among the most used growth regulators in the cuttings rooting, is the IBA, because of its efficiency, its stability and lower toxicity in large concentration range (ALVARENGA; CARVALHO, 1983; IRITANI et al., 1986). Its action is related to the synthesis of nucleic acids and proteins, cell wall alterations and enzymatic activities increase (FIGUEIREDO et al., 1995). On the other hand, the cutting behavior concerning phytoregulators varies according to the species, the clone (CHUNG, LEE, 1994), the propagating material maturation state, the cutting type, time of year, concentration and application method (BASTOS, 2006).

Considering the mini-cutting importance in the teak cloning, the present work aimed to evaluate the application of IBA $(0,1000,2000,4000,8000$ e 16000 $\left.\mathrm{mg} \mathrm{L}^{-1}\right)$ in the survival and in the mini-cutting rooting and growth in height and in collar diameter and the biomass air part and the seedling root system of four Tectona grandis clones.

\section{MATERIALAND METHOLODOGY}

This study was carried out from October to December in 2013, in the forest nursery of Agrícola Verde Novo Ltda. company, located in the Colíder, Mato Grosso, Brasil. In according with Köppen1's classification, the North region of Mato Grosso presents Awi clime, that is to say, rainy tropical with two-month dry clear season; annual average temperature about $25^{\circ} \mathrm{C}$, with annual average rain $2.200 \mathrm{~mm}$; with latitude of $10^{\circ} 57^{\prime} 21^{\prime \prime}$ $\mathrm{S}$, longitude $55^{\circ} 32^{\prime} 55^{\prime \prime}$ and average altitude of 256 m (MATO GROSSO, 2008).

It was used mini-cuttigs of four Tectona grandis clones (Carapá, Ipê, GU5 and TB7), which were collected in mini-stumps established in mini-clonal hedge on hydroponic system, with management and nutrition according to the procedures used by the Agrícola Verde Novo Ltda company. 


\subsection{Clonal Minigarden management}

According the teak propagation technique by minicutting adopted by the Agrícola Verde Novo company Ltda., the clonal mini-garden was installed in heated greenhouse, covered with transparent polyethylene and shade cloth of $60 \%$ reduction in brightness, on the walls and ceiling in order to maintain temperature lower than $35^{\circ} \mathrm{C}$ and relative humidity above $85 \%$. It is consisted of mini-stumps obtained by rooting cuttings, implemented in spacing of $10 \times 10 \mathrm{~cm}$ in channels of fiber cement without asbestos, with RCSS (Reinforced Cement with Synthetic Strings), filled with crushed stone at the bottom and washed sand.

The mineral fertilization of clonal mini-garden was performed with a nutrient solution composed of calcium nitrate $\left(0.5 \mathrm{~g} \mathrm{~L}^{-1}\right)$, potassium nitrate $\left(0.5 \mathrm{~g} \mathrm{~L}^{-1}\right)$, monoammonium phosphate $\left(0.15 \mathrm{~g} \mathrm{~L}^{-1}\right)$, boric acid $(2.5$ $\left.\mathrm{mg} \mathrm{L}^{-1}\right)$, sodium molybdate $\left(2.5 \mathrm{mg} \mathrm{L}^{-1}\right)$ copper chelate $\left(0.0015 \mathrm{~mL} \mathrm{~L}^{-1}\right)$, zinc chelator $\left(0.0005 \mathrm{~mL} \mathrm{~L}^{-1}\right)$, manganese chelate $\left(0.005 \mathrm{~mL} \mathrm{~L}^{-1}\right)$, chelate of iron $\left(0.0075 \mathrm{~mL} \mathrm{~L}^{-1}\right)$ applied with an automated drip fertigation, activated once a day in the evening. Excess nutrient solution was drained by the channel bottom and was discarded. Irrigation was carried out by a sprinkler system, triggered from two to five times a day, to maintain the temperature lower than $35^{\circ} \mathrm{C}$ and relative humidity above $85 \%$ within the greenhouse.

\subsection{Obtaining, preparation and mini-cuttings staking}

The mini-cuttings were collected in the established mini-stumps in the clonal mini-garden, prepared with dimensions of 4-6 cm in length, keeping two pairs of leaves reduced to $1 / 4$ its original dimension. To maintain turgidity conditions of vegetative material, the minicuttings were packaged in Styrofoam boxes, performing spraying with water by hand sprayer at time intervals of less than five minutes to the treatments. The period between the mini-cutting collection, the preparation and subsequent staking, was always less than 20 minutes.

For the assessment of the IBA effect on rooting, the treatments were $0,1000,2000,4000,8000$ and 16000 $\mathrm{mg} \mathrm{L}^{-1}$, diving approximately $1 \mathrm{~cm}$ from the base of the mini-cuttings in the solution for about 10 seconds. Then, the cuttings were planted in ellepotes (dimensions: 6 $\mathrm{cm}$ and diameter $3.5 \mathrm{~cm}$ ) filled with commercial substrate CAROLINA II BR (composition: peat sphagno (40.5\%), expanded vermiculite (34.5\%), carbonized rice husk (24\%), dolomite (1\%), gypsum ( $0.5 \%)$, NPK fertilizer (strokes), $\mathrm{pH} 5.5$ and electrical conductivity $\left.\left(\mathrm{mS} \mathrm{cm}^{-1}\right) 0.7\right)$.

The cuttings, after staking, were taken to a greenhouse for rooting, which is covered with transparent polyethylene and shade cloth of $60 \%$ reduction in brightness, on the walls and ceiling, trying to keep the temperature less than $35^{\circ} \mathrm{C}$ and air relative humidity above $95 \%$ with a irrigation frequency of 30 seconds every 20 minutes, where they remained for 15 days. Afterwards, they were transferred to acclimatization in a greenhouse with similar infrastructure characteristics but with a frequency of irrigation of 30 seconds every 60 minutes, remaining for 15 days. Later, they were transferred to the shade house with polyethylene and shade cloth of $70 \%$ reduction in light, where they stayed for 10 days and finally were transferred to the growth patio in full sun for the final evaluations carried out at 55 after staking.

It was adopted a factorial arrangement ( $4 \times 6)$, considering the four clones studied and six doses of IBA in statistical design of random blocks, with three replications and 16 installments of mini-cuttings.

\subsection{Experimental evaluations}

The evaluations were performed about the survival percentage and mini-cuttings rooting out of the greenhouse (after 30 days of staking) and survival out of the shade house (40 days after staking). The rooting was evaluated when it was observed the appearance of the roots that grew in the ellepot walls.

In full sun area (55 days after staking), it was evaluated survival, height $(\mathrm{h})$, the stem diameter (sd) and the dry mass weight of aerial part (WAP) and root system (RS) of obtained seedlings. The height measurement was made with graduated ruler in $\mathrm{mm}$ and a neck diameter using digital caliper. For the determination of WAP and RS, four mini-cuttings / repetition were sampled, considering average values of height growth of seedlings in full sun area, and the obtained plant material, led to the forced circulation greenhouse of air at $60^{\circ} \mathrm{C}$ to the weight constant.

From the data found for the evaluated characteristics, the analysis of variance and Tukey test at $95 \%$ probability were performed using the SAS System for Windows program (Statistical Analysis System), version 6.12.

Revista Árvore, Viçosa-MG, v.40, n.3, p.477-485, 2016

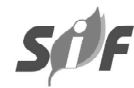




\section{RESULTS}

The analysis results of the survival characteristics (GO) and roots (ENR) evaluated in the greenhouse output and survival in the shade house output (SHO) (Table 1) revealed a significant difference $(\mathrm{P}>0.95)$ between the clones used in the experiment, which suggests genetic variability among these materials concerning the adventitious rooting capacity of mini-cuttings. However, there was no significant difference in the use of IBA concentrations, as well as significant interaction was not found "clone $\mathrm{x}$ dose" $(\mathrm{P}>0.95)$ by $\mathrm{F}$ test about the characteristics evaluated.

The experimental variation coefficients found ranges from $6.93 \%$ to $9.72 \%$, showing good levels of experimental precision in relation to the characteristics studied, according the literature review (XAVIER; COMÉRIO, 1996; RIBAS, 1997; WENDLING et al., 2000; TITON 2001;. WEDLING, 2002).

The clone that showed the highest percentage for the characteristics evaluated, was the clone Ipê, followed by Carapá, Gu5 and TB7. Survival percentages in the greenhouse output of Ipê , Carapá and GUS clones showed values above $90 \%$, while the clone TB7 showed values in the range of $80-90 \%$ (Figure 1 ).

A reduction in the cuttings survival in the shade house output was observed in relation to the greenhouse, however, maintaining the same trend. Concerning the survival at 55 days (full sun), changes were not observed with respect to the record made in the shade house output.

With the results of the characteristics evaluated in full sun for 55 days after staking is possible to observe statistical differences between clones for height (h) and diameter ( $\mathrm{dc})$, and with average of $11.77 \mathrm{~cm}$ and $3.79 \mathrm{~mm}$ respectively. Nonetheless, statistical differences were not observed when different concentrations of IBA to the interaction "Clone $\mathrm{x}$ Dose" are applied $(\mathrm{P}>0.95)$ by F-test (Table 2$)$.

In respect of the growth in height and stem diameter of seedlings 55 days after staking, it was found that the Carapá clones, GU5 and Ipe showed similar responses, differing from TB7 clone that showed the lowest value (Figure 2a). For the characteristics stem diameter, the clone with the highest value was TB7, followed by GU5, Ipê and Carapá (Figure 2b).

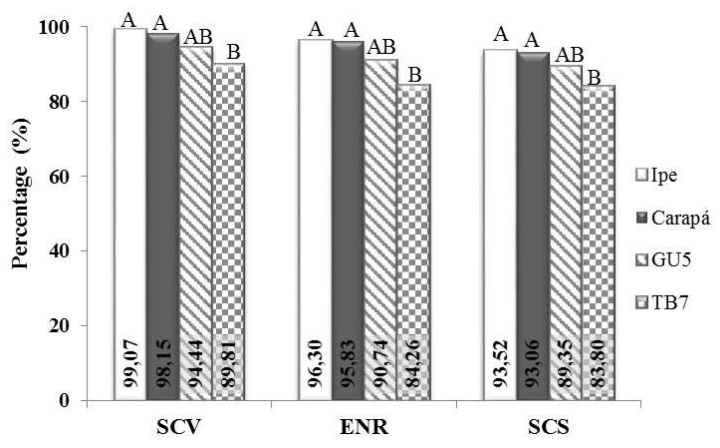

Figure 1 - Mini-cutting survival (SCV) and rooting percentage (ENR) from greenhouse, as well as survival percentage (SCS) from shadow house, on four Tectona grandis clones. Mean values under same letter are significantly similar based on Tukey's test at $\mathrm{p}>0.95$.

Figura 1-Porcentual de sobrevivência (SCV) e de enraizamento (ENR) de miniestacas na saída da casa de vegetação, e sobrevivência (SCS) na saída da casa de sombra, dos quatro clones de Tectona grandis. Médias seguidas da mesma letra não diferem entre si, pelo teste de Tukey, a 95\% de probabilidade.

Table 1 - Summary of variance analyses on survival (SCV) and rooting from greenhouse (ENR), as well as survival from shadowhouse (SCS), as a result of six IBA application dosages in four Tectona grandis clones.

Tabela 1 - Resumo da análise de variância de sobrevivência (SCV) e de enraizamento na saída da casa de vegetação (ENR) e de sobrevivência na saída da casa de sombra (SCS), em função da aplicação de seis doses de AIB, em quatro clones de Tectona grandis.

\begin{tabular}{|c|c|c|c|c|c|c|c|c|c|c|}
\hline \multirow{2}{*}{$\begin{array}{l}\text { Source of } \\
\text { variation }\end{array}$} & \multirow[t]{2}{*}{$\mathrm{df}$} & \multicolumn{3}{|c|}{ SCV $(\%)$} & \multicolumn{3}{|c|}{ ENR (\%) } & \multicolumn{3}{|c|}{ SCS (\%) } \\
\hline & & $\begin{array}{c}\text { Mean } \\
\text { square }\end{array}$ & $\mathrm{F}$ & $\mathrm{P}$ & $\begin{array}{l}\text { Mean } \\
\text { square }\end{array}$ & $\mathrm{F}$ & $\mathrm{P}$ & $\begin{array}{l}\text { Mean } \\
\text { square }\end{array}$ & $\mathrm{F}$ & $P$ \\
\hline Clone (C) & 3 & 318,93 & 8,92 & $0,0012 * *$ & 566,81 & 10,87 & $0,0005 * * *$ & 363,612 & 5,59 & $0,0089 * *$ \\
\hline Dosage (D) & 5 & 22,38 & 0,63 & $0,6827^{\mathrm{ns}}$ & 26,43 & 0,51 & $0,7668^{\text {ns }}$ & 57,29 & 0,88 & $0,5171^{\text {ns }}$ \\
\hline$(\mathrm{C}) *(\mathrm{D})$ & 15 & 35,75 & 0,82 & $0,6537^{\mathrm{ns}}$ & 52,15 & 0,67 & $0,8032^{\mathrm{ns}}$ & 65,01 & 0,85 & $0,6203^{\mathrm{ns}}$ \\
\hline Mean & & 95,37 & & & 91,78 & & & 89,93 & & \\
\hline $\mathrm{CV}_{\exp }(\%)$ & & 6,93 & & & 9,64 & & & 9,72 & & \\
\hline
\end{tabular}

ns, ${ }^{*},{ }^{*} \mathrm{e}^{* * *}:$ : non-significant to 0,05 ; significant to 0,$05 ; 0,01$ and 0,001 de probability (P), respectively, by de $\mathrm{F}$ test. 
Table 2 - Summary of variance analyses on height (h) and collar diameter (dc) as a result of six IBA application dosages in four Tectona grandis clones, 55 days after sowing.

Tabela 2 - Resumo da análise de variância da altura (h) e do diâmetro de colo (dc), em função da aplicação de seis doses de AIB em quatro clones de Tectona grandis, aos 55 dias após estaqueamento.

\begin{tabular}{|c|c|c|c|c|c|c|c|}
\hline \multirow{2}{*}{$\begin{array}{l}\text { Source of } \\
\text { variation }\end{array}$} & \multirow[b]{2}{*}{ df } & \multicolumn{3}{|c|}{$\mathrm{h}(\mathrm{cm})$} & \multicolumn{3}{|c|}{$\mathrm{dc}(\mathrm{mm})$} \\
\hline & & $\begin{array}{l}\text { Mean } \\
\text { square }\end{array}$ & $\mathrm{F}$ & $\mathrm{P}$ & $\begin{array}{l}\text { Mean } \\
\text { square }\end{array}$ & $\mathrm{F}$ & $\mathrm{P}$ \\
\hline Clone (C) & 3 & 81,041 & 29,29 & $<, 0001 * * *$ & 1,107 & 17,02 & $<, 0001 * * *$ \\
\hline Dosage (D) & 5 & 8,609 & 3,11 & $0,0401 *$ & 0,089 & 1,37 & $0,2886^{\mathrm{ns}}$ \\
\hline$(\mathrm{C}) *(\mathrm{D})$ & 15 & 2,767 & 0,97 & $0,4988^{\mathrm{ns}}$ & 0,065 & 0,46 & $0,9480^{\text {ns }}$ \\
\hline Mean & & 11,77 & & & 3,79 & & \\
\hline $\mathrm{CV}_{\exp }(\%)$ & & 14,33 & & & 9,89 & & \\
\hline
\end{tabular}

ns, $*, * \mathrm{e}^{* * *}:$ non-significant to 0,$05 ;$ significant to 0,$05 ; 0,01$ and 0,001 de probability $(\mathrm{P})$, respectively, by de $\mathrm{F}$ test.
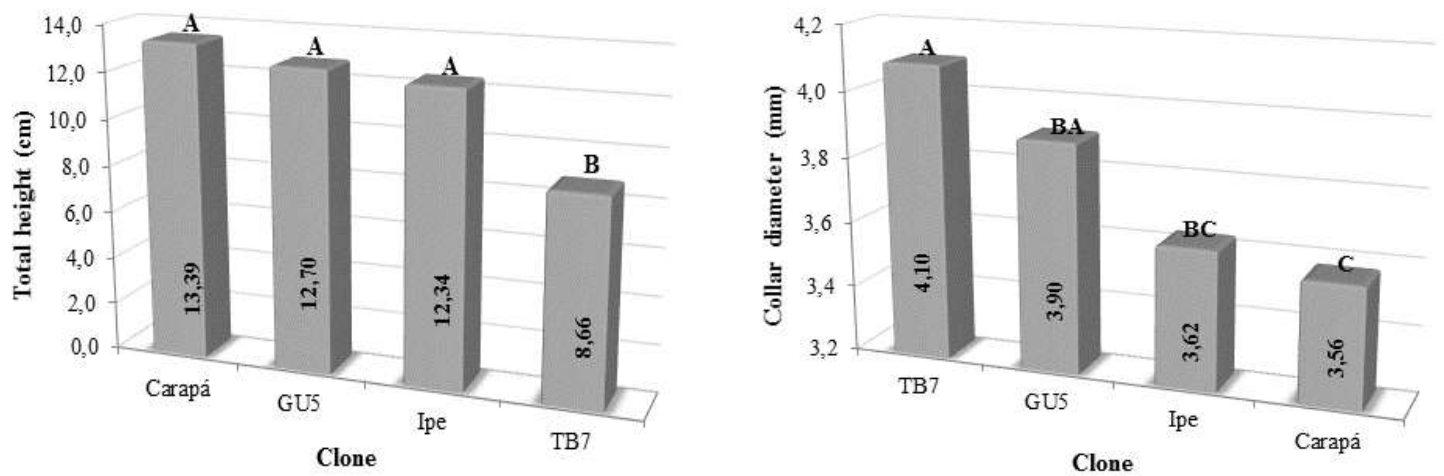

Figure 2 - Total height $(\mathrm{cm})$ and collar diameter $(\mathrm{mm})$ mean values in mini-cuttings from four Tectona grandis clones, in relation to IBA treatments, 55 days after sowing at sun exposure conditions. Mean values under same letter are significantly similar based on Tukey's test at $\mathrm{p}>0.95$.

Figure 2 - Valores médios de altura total ( $\mathrm{cm}$ ) e diâmetro de colo ( $\mathrm{mm}$ ) de mudas de quatro clones Tectona grandis, em função dos tratamentos de AIB, após 55 dias do estaqueamento a pleno sol. Médias seguidas da mesma letra não diferem entre si, em nível de $95 \%$ de probabilidade, pelo teste Tukey.

Regarding the results obtained for dry biomass of the aerial part (AP) and biomass of the roots system (RS), 55 days after staking, a significant difference between the clones was found (Table 3 ). However, significance in the use of different concentrations of IBA and interaction "Clone $x$ Dose" was not found $(\mathrm{P}<0.95)$ by F test.

The experimental variation coefficients for the variables studied in full sun, height, stem diameter, aerial part biomass and root biomass varied from $9.30 \%$ to $14.33 \%$, indicating good levels of experimental precision, agreeing with values found in the literature review (RIBAS, 1997; WENDLING et al., 2000; TITON, 2001).

\section{DISCUSSION}

Overall, it was not found significant difference in survival and rooting in the greenhouse output, in survival in the shade house output, in height and stem diameter, dry biomass weight of aerial part and root system, in vegetative propagation of teak by mini-cuttings rooting due to the application of IBA doses. However, behavior characteristics demonstrated statistically significant differences with respect to the tested clones, which corroborate the statements of Hartmann et al. (2011), which highlight that it is common that each genetic material responds differently to vegetative propagation.

In the greenhouse output a high percentage of survival was obtained, demonstrating adequate control of environmental conditions (temperature and humidity), which were favorable to maintaining the propagating material survival (TITON, 2001; WEDLING; XAVIER, 2005).

Revista Árvore, Viçosa-MG, v.40, n.3, p.477-485, 2016 
Table 3 - Summary of variance analyses on aerial biomass (PPA) and rot system biomass (PSR), as a result of six IBA application dosages in four Tectona grandis clones, 55 days after sowing.

Tabela 3 - Resumo da análise de variância da biomassa parte aérea (PPA) e biomassa do sistema radicial (PSR) em função da aplicação de seis doses de AIB em quatro clones de Tectona grandis, aos 55 dias após de estaqueamento.

\begin{tabular}{|c|c|c|c|c|c|c|c|}
\hline \multirow{2}{*}{$\begin{array}{l}\text { Source of } \\
\text { Variation }\end{array}$} & \multirow[t]{2}{*}{$\mathrm{df}$} & \multicolumn{3}{|c|}{ PPA (g) } & \multicolumn{3}{|c|}{ PSR (g) } \\
\hline & & Mean square & $\mathrm{F}$ & $\mathrm{P}$ & Mean square & $\mathrm{F}$ & $\mathrm{P}$ \\
\hline Clone (C) & 2 & 0,162 & 5,86 & $0,0074 *$ & 0,025 & 3,82 & $0,0623^{\mathrm{ns}}$ \\
\hline Dosage (D) & 3 & 0,071 & 2,60 & $0,0693^{\mathrm{ns}}$ & 0,016 & 2,44 & $0,0831^{\mathrm{ns}}$ \\
\hline$(\mathrm{C}) *(\mathrm{D})$ & 5 & 0,027 & 0,65 & $0,8193^{\text {ns }}$ & 0,006 & 0,36 & $0,9829^{\text {ns }}$ \\
\hline Mean & 15 & 1,00 & & & 1,02 & & \\
\hline $\mathrm{CV}_{\mathrm{exp}}(\%)$ & & 10,56 & & & 9,30 & & \\
\hline
\end{tabular}

ns, $* * * \mathrm{e}^{* * *}$ : non-significant to 0,05 ; significant to 0,$05 ; 0,01$ and 0,001 de probability $(\mathrm{P})$, respectively, by de $\mathrm{F}$ test.

The undifferentiated response of teak mini-cuttings due to the IBA application may be related to good nutrition mini-stumps in clonal garden, the degree of juvenility / reinvigoration of materials and good management of greenhouse environmental conditions. According to Paiva and Gomes (2005), the mini-cutting rooting is directly linked to weather conditions and the carbohydrate content stored in the matrix; the higher the reserves level and the higher the carbon / nitrogen ratio, the greater favoring the formation of roots on cuttings. Other authors mention that the response of clones compared to the use of IBA may be associated with material aging conditions, the shading, the presence of leaves and buds; the mother plant age, differences in the genetic material, environmental conditions such as water availability, light incidence and substrate, among other factors (CHUNG; LEE, 1994; WILSON, 1994; KAMLESH et al., 1995;. HARTMANN et al., 2011). However, the use of mini-cutting technique, compared to the traditional technique of cutting, has led to use of lower concentrations of IBA and in some cases even its suppression (ASSIS et al., 1992; XAVIER; COMÉRIO, 1996; ASSIS, 1997).

The literature review has reported to non-influence the IBA on rooting of young propagating material, for example, to Ilex paraguariensis (WENDLING; SOUZA JUNIOR, 2003), Cedrella fissilis (XAVIER et al., 2003), Grevillea robusta (SOUZA JUNIOR et al. , 2008) and loblolly pine (ALCANTARA et al., 2008). Also in studies by Pereira et al. (2005), different concentrations of IBA $\left(0 ; 1000 ; 2000 ; 4000\right.$ and $\left.6000 \mathrm{mg} \mathrm{L}^{-1}\right)$ did not affect the rooting percentage of Brazilian grape tree apical cuttings (Myrciaria jabuticaba). The same result was obtained by Pio et al. (2006), for the rooting of apical cuttings Ficus carica L, 0 and $2000 \mathrm{mg} \mathrm{L}^{-1}$ IBA.

Revista Árvore, Viçosa-MG, v.40, n.3, p.477-485, 2016
During the time in the shade house, it was observed mortality only of mini-cuttings that did not have root system or those in which it was very little developed in the acclimatization house output (4 weeks after staking), which could be a result of transfer to an environment with less control of environmental conditions (FERREIRA et al., 2004; FREITAS et al, 2006;. MELO et al., 2011.). The clones' different behavior regarding survival in the greenhouse output and in the shade house output was also verified by Wendling et al. (2000) when he worked with the propagation Eucalytus spp. Clones.

The height and stem diameter are characteristics that have been used to estimate the standard of quality of seedlings in the forest nurseries, with the advantage of these evaluations are not destructive and easy to measure. For teak, it has not yet set a criterion to standardize these characteristics. About the clones studied, they showed different growth in height and stem diameter. However, within each clone, differences were not observed between IBA doses. These results demonstrate that the IBA doses used did not have influence on seedlings growth, with the reservation that this characteristic, in according with Carneiro (1995), can be easily modified according to management of seedling production.

In the evaluation of dry biomass of aerial part and the root system differences in dosages applied were not found. Titon et al. (2003) did not find difference in the IBA application $\left(0,1000,2000\right.$ and $\left.4000 \mathrm{mg} \mathrm{L}^{-1}\right)$ in four clones of Eucalyptus grandis, on height and stem diameter of seedlings at 50 days old. Lana et al. (2008), in the evaluation of IBA different concentrations effects in rooting of cuttings and growth of Eucalyptus urophylla seedlings, they found that the dry mass of roots was not influenced by the application of growth regulato 


\section{CONCLUSIONS}

The use of different doses of IBA did not show effect on the survival, on rooting, on height, on diameter, on the aerial part biomass and root system of the evaluated clones, but a differential response among the four clones was observed, suggesting effect genotypic.

\section{ACKNOWLEDGMENTS}

For The Ministry of Science and Technology (MICIT-CONICIT) and Costa Rica Technological Institute (TEC), for the scholarships grating and the Agricultural company Verde Novo Ltda., for the financial support and infrastructure.

\section{REFERENCES}

ALCÂNTARA, G. B.; RIBAS, L.; RIOYEI, A.; ZUFFELLATO, K.C. Efeitos do ácido indolilbutírico (AIB) e da coleta de brotações em diferentes estações do ano no enraizamento de miniestacas de Pinus taeda L. Scientia Forestalis, v. 36, n. 78, p. 151-156, 2008.

ALVARENGA, L. R.; CARVALHO, V. D. Uso de substâncias promotoras de enraizamento de estacas frutíferas. Informe Agropecuário, v. 9, p. 47-55, 1983.

ASSIS, T. F. Propagação vegetativa de Eucalyptus por microestaquia. In: IUFRO CONFERENCE ON SILVICULTURE AND IMPROVEMENT OF EUCALYPTS, 1997, Salvador. Proceedings... Colombo: Embrapa, 1997. v. 1. p. 300-304.

ASSIS, T. F.; ROSA, O. P.; GONÇALVES, S. I. Propagação por microestaquia. In: CONGRESSO FLORESTAL ESTADUAL, 7, 1992, Nova Prata. Anais... Santa Maria, RS: UFSM, 1992. p. 824836.

BASTOS, D. C. Propagação da caramboleira por estacas caulinares e caracterização anatômica e histológica da formação de raízes adventícias. 2006. 66 f. Tese (Doutorado em Agronomia) - Escola Superior de Agricultura "Luiz de Queiroz", Piracicaba, 2006.

CARneiro, J. G. A. Produção e controle de qualidade de mudas florestais. Curitiba: UFPR/FUPEF, 1995. 451 p.
CHUNG, D. Y.; LEE, K. J. Effects of clones, ortet age, crown position, and rooting substance upon the rooting of cuttings of Japanese larch (Larix leptolepis S. et Z. Gordon). Forestry

Genetics Research Institute, v. 83, n. 2, p. 205-210, 1994.

DE KLERK, G.J.; VAN DER, W.; DE JONG, J. Review the formation of adventitious roots: New concepts, new possibilities. In Vitro

Cellular \& Developmental Biology Plant, v.35, p. 189-199, 1999.

FERRERIA, E. M.; ALFENAS, A.; MAFIA, R.; LEITE, H.; SARTORIO, R.; PENCEL, R.

Determinação do tempo ótimo de enraizamento de clones de Eucalyptus spp. Revista Árvore, v. 28, n.2, p. $183.187,2004$.

FIGUEIREDO, S. L. B.; KERSTEN, E.; SCHUCH, M. W. Efeito do estiolamento parcial e do ácido indolbutírico (IBA) no enraizamento de estacas de ramos de goiabeira serrana (Feijo asellowiana, Berg). Scientia Agrícola. v. 52, n. 1, p. $167-$ 171. 1995 .

FREITAS, T.A.S.; BARROSO, D.; CARNEIRO, J.G.; PENCHEL, R.; FIGUEIREDO, F. Mudas de eucalipto produzidas a partir de miniestacas em diferentes recipientes e substratos. Revista Árvore, v. 30, n. 4. p. 519-528, 2006.

GATTI, K. C. Propagação vegetativa de pau mulato (Calycophyllyum supreceanum (Benth) K. Schum), jequitibá (Cariania estrellensis (Raddi) Kuntze) e teca (Tectona grandis Linn. f.) por miniestaquia. 2002. 72 f. Dissertação (Mestrado em Ciências Florestais) - Universidade Federal de Viçosa. Viçosa, MG, 2002.

GOH, D. K. S.; GALIANA, A. Vegetative propagation of teak. JIRCAS working Report. n. 16, p. 35-43. 2000.

HARTMANN, H. T.; KESTERL, D.E.; DAVIES JUNIOR, F.T.; GENEVE, R.L. Plant propagation: principles and practices. 8 ed. Boston: Prentice Hall, 2011.915 p.

HUSEN, A. Rejuvenation and adventitious rooting in coppice-shoot cuttings of Tectona grandis as affected by stock-plant etiolation. American Journal of Plant Sciences, v.2, p. 370-374, 2011.

Revista Árvore, Viçosa-MG, v.40, n.3, p.477-485, 2016

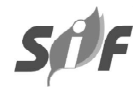


IRITANI, C.; SOARES, R. V.; GOMES, A. V. Aspectos morfológicos da aplicação de reguladores do crescimento nas estacas de Ilex paraguariensis St. Hilaire. Acta Biológica Paranaense, v. 15, p. 21-46, 1986.

KAMLESH, K.; SWAMY, S.; SEHGAL, R.; KHOSLA, P. Effect of auxins and carbendazim on rooting of juvenile and mature stem cuttings of Grewia optiva. Indian Journal of Forestry, v. 18, n. 1, p. 61-65, 1995.

KAOSA-ARD, A. Teak breeding and improvement strategies. In: Teak for the future. Proceeding of the Second Regional Seminar on Teak, Yangon, Myanamar, 29 May - 3 June 1998. p. 61-81. Bankok, Thailand, FAO Regional Office for Asia and the Pacific. Disponível em: http:// www.fao.org/docrep/005/ac7773e/ ac773e08.htm\#bm08.2. Acesso em: 31 mar. 2014

LAMPRECHT, H. Silvicultura nos trópicos: ecossistemas florestais e respectivas espécies arbóreaspossibilidades e métodos de povoamento sustentado. Eschborn: Instituto de Silvicultura da Universidade de Göttingen, 1990. p.310-313.

LANA, A. M. Q.; LANA, Â. M. Q.; BARREIRA, S.; MORAIS, T. R.; FARIA, M. V. Doses do ácido indolbutírico no enraizamento e crescimento de estacas de eucalipto (Eucalyptus urophylla). Bioscience Journal. v. 24, n. 3, p. 13-18, 2008.

MASCARENHAS, A. F.; MURALIDEHARAN, E. M. Clonal forestry with tropical harwoods. In: AHUJA, M.R.; LIBBY, W.J. Clonal forestry II, conservation and application. Germany: Springer Verlag. 1993, p. 169-187.

MATO GROSSO. Secretaria de Estado de Planejamento. Anuário estatístico de Mato Grosso de 2007. Cuiabá: Carlini e Caniato Editorial, 2008. 762 p.

MELO, L. A.; XAVIER, A.; DE PAIVA, H. N.; BORGES, S. R.. Otimização do tempo necessário para o enraizamento de miniestacas de clones híbridos de Eucalyptus grandis. Revista Árvore, v. 35, n. 4, p. 759-767, 2011.
MONTEUUIS, O.; BON, M. C.; GOH, D. K. S. Teak propagation by in vitro culture. Bois et Forêts des Tropiques, v. 256, p. 43-53, 1998.

MONTEUUIS, O.; VALLAURI, D.; POUPARD, C.; HAZARD, L.; YUSOF, Y.; WAHAP LATIP, A.; GARCIA, C.; CHAUVIERE. M. Propagation clonale de tecks matures par bouturage horticole. Bois et Forêts des Tropiques, v. 243, p. 25-39, 1995.

MURILLO O.; BADILLA, Y. Breeding teak in Costa Rica. In: Li B, Mackeand, S. (Eds).

Forestry genetics and tree breeding in the age of genomics - progress and future. Raleigh: North Carolina State University. 2004a, p. 105-110.

MURillo, O.; BADilla Y. Potencial de mejoramiento genético de la teca en Costa Rica. In: SEMINARIO Y GRUPO DE DISCUSIÓN TECA (Tectona grandis). . 2004b Disponível em: http://www.una.ac.cr/ins/ discusion/articulos.htm. Acceso em: 26 mar. 2014.

OLIVEIRA, J. R. V. Sistema para cálculo de balanço nutricional e recomendação de calagem e adubação de povoamentos de teca - Nutriteca. 2003. 93 f. Dissertação (Mestrado em Solos e Nutrição de Plantas) - Universidade Federal de Viçosa, Viçosa-MG, 2003.

ONO, E. O.; RODRIGUES, J. D. Aspectos da fisiologia do enraizamento de estacas caulinares. Jaboticabal: FUNEP, 1996. 83 p.

PAIVA, H. N.; GOMES, J. M. Propagação vegetativa de espécies florestais. Viçosa, MG: UFV, 2005. 46p. (Caderno Didático, 83).

PEREIRA, M.; OLIVEIRA, A. D.; GONÇALVES, A. N.; ALMEIDA, M. D. Efeitos de substratos, valores de $\mathrm{pH}$, concentrações de AIB no enraizamento de estacas apicais de jabuticabeira [Myrciaria jabuticaba (Vell.) O. Berg.] Scientia Forestalis, Instituto de Pesquisas e Estudos Florestais. Piracicaba: IPEF - SP, dez. (69): 84-92.

PIO, R.; RAMOS, J. D.; CHALFUN, N. N. J., GONTIJO, T. C. A.; MENDONÇA, V.; CARRIJO, E. P.; CHAGAS, E. A. Propagação de estacas 
apicais de figueira: diferentes ambientes, ácido indolbutírico e tipo de estaca. Ciência e Agrotecnologia, v. 30, n. 5, p.1021-1026. 2006.

RIBAS, K.C. Interações entre auxina e cofatores de enraizamento na promoção do sistema radicular em estacas de Eucalyptus grandis W. Hill ex Maiden. Botocatu, Sp: UNESP, 1997. $150 \mathrm{f}$.

SOUZA JUNIOR, L.; QUOIRIN, M.; WENDLING, I. Miniestaquia de Grevillea robusta A. Cunn. a partir de propágulos juvenis. Ciência Florestal, v. 18, n. 4, p. 455-460, 2008.

TITON, M. Propagação clonal de Eucalyptus grandis por miniestaquia e microestaquia. 2001. 65 f. Dissertação (Mestrado em Ciência Florestal) - Universidade Federal de Viçosa, Viçosa-MG, 2001.

TITON, M.; XAVIER, A.; OTONI, W. C.; REIS, G. D. Efeito do AIB no enraizamento de miniestacas e microestacas de clones de Eucalyptus grandis W. Hill ex Maiden. Revista Árvore, v.27, n.1, p. 1-7. 2003.

WEDLING, I.; XAVIER, A. Influencia do ácido indolbutirico e da miniestaquia seriada no enraizamento e vigor de miniestacas de clones de Eucalyptus grandis. Revista Árvore, v. 29, n. 6. p. 921-930. 2005 .

WENDLING, I.; XAVIER, A.; GOME S, J. M.; PIRES, I. E.; ANDRADE, H. B. Efeito do regulador de crescimento AIB na propagação de clones de Eucalyptus spp. por miniestaquia. Revista Árvore, v. 24, n.2, p. 187-192. 2000.

WEndling, I. Propagação clonal de híbridos de Eucalyptus spp. por miniestaquia. Viçosa, MG: UFV, 1999. $70 \mathrm{f}$. Dissertação (Mestrado em Ciência Florestal)Universidade Federal de Viçosa, 1999.
WENDLING, I. Rejuvenescimento de clones de Eucalyptus grandis por miniestaquia seriada e micropropagação. $2002.98 \mathrm{f}$. Tese

(Doutorado em Ciência Florestal) Universidade Federal de Viçosa, Viçosa-MG, 2002.

WENDLING, I.; SOUZA JUNIOR, L. Propagação vegetativa de erva-mate (Ilex paraguariensis Saint Hilaire) por miniestaquia de material juvenil. In: CONGRESSO SUL-AMERICANO DA ERVAMATE, 3. FEIRA DO AGRONEGÓCIO DA ERVAMATE, 2003, Chapecó. Anais...Chapecó: EPAGRI, 2003.

WILSON, P. J. The concept of a limiting rooting morphogen in woody stem cuttings. Journal of Horticultural Science, v. 9, n. 4, p. 391 - 400, 1994.

XAVIER, A.; SANTOS, G. D.; WENDLING, I.; OLIVEIRA, M. D. Propagação vegetativa de cedro-rosa por miniestaquia. Revista Árvore, v. 27, p. 139-143, 2003.

XAVIER, A., COMÉRIO, J. Microestaquia: uma maximização da micropropagação de Eucalyptus. Revista Árvore, v.20, n.1, p.9$16,1996$.

XAVIER, A.; WENDLING, I. Miniestaquia na clonagem de Eucalyptus. Viçosa, MG: SIF, 1998. 10 p. (Informativo Técnico SIF, 11).

XAVIER, A.; WENDLING, I.; SILVA, R. L. Silvicultura clonal: princípios e técnicas. 2 Ed. Viçosa, MG. Ed. UFV, 2013. $279 \mathrm{p}$.

ZUFFELLATO-RIBAS, K. C.; RODRIGUES, J. D. Estaquia: uma abordagem dos principais aspectos fisiológicos. Curitiba: UFPR, 2001.39 p. 